\title{
PRISON AS A TORTUROUS INSTITUTION
}

\author{
Jessica Wolfendale
}

\begin{abstract}
Philosophers working on torture have largely failed to address the widespread use of torture in the U.S. prison system. Drawing on a victim-focused definition of torture, I argue that the U.S. prison system is a torturous institution in which direct torture occurs (the use of solitary confinement) and in which torture is allowed to occur through the toleration of sexual assault of inmates and the conditions of mass incarceration. The use and toleration of torture expresses and reinforces the moral exclusion of those subjected to it, particularly African Americans. Importantly, this moral exclusion and the experience of torture may be created and reinforced through institutional practices independently of the intentions of individuals acting within those institutions. By prioritizing torture victims' experiences and severing the link between torture and intention, my account forces a recognition that, far from being inconsistent with U.S. values, torture is deeply embedded within U.S. institutions.
\end{abstract}

The torture debate in philosophy has focused almost exclusively on the use of torture in the context of terrorism. Authors defending the possibility of justified torture, such as Jeff McMahan (2018), Fritz Allhof (2012), and Uwe Steinhoff (2013), often make use of hypothetical cases such as 'ticking bomb' scenarios to defend the view that torture could in rare cases be justified. Other authors have critiqued the use of these hypotheticals for being unrealistic, misleading, and irrelevant to the realities of torture. ${ }^{1}$ This back-and-forth between defenders of torture in ticking bomb cases and critics of such cases has effectively defined the contours of the torture debate in America since 9/11. This debate is characterized by an individualized narrative of torture that renders torture simultaneously hypervisible by asking us to consider whether torturing this person (whether real or hypothetical) is permissible yet makes the reality and true scope of torture invisible. Thus, philosophers have largely failed to see and address the scope and function of torture in U.S. society-in particular, the widespread use of torture in U.S. prisons, jails, and detention centers. Thus, they have

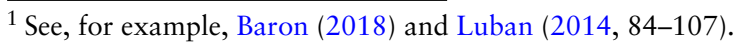


failed to recognize that, far from being antithetical to U.S. values, torture is deeply embedded within central U.S. institutions.

To see the true scope and function of torture in the United States, we need to start not from hypothetical cases but from the reality of torture. In Section 1, I draw on philosophical and survivor accounts of torture to develop what I call an experiential definition of torture based on torture's distinctive experiential imprint. The experience of torture is characterized by complete vulnerability to extreme suffering in a context of domination. This experience has the potential to radically undermine victims' embodied sense of self and reality and to shatter the capacity for moral trust in the world. Accounts of torture victims also reveal that one of the defining functions of torture, regardless of the context in which it is used, is to express and reinforce the moral exclusion of those who are deemed torturable. Because torture represents the complete rejection of basic moral recognition, who is viewed as torturable tells us who in our society "gets banned or expelled" (Dayan 2011,22) from the realm of moral consideration.

In Section 2, I show how the conception of torture that I defend makes it possible to see how institutional structures, norms, and practices not previously conceptualized as torture can create the conditions of radical vulnerability to suffering and serve the function of moral exclusion independently of the intentions of agents acting within those structures. Institutions structured by such relationships of domination and moral exclusion are what I call torturous institutions: institutions in which certain groups are made vulnerable to torture and where such vulnerability is sustained and reinforced by social, political, and legal narratives of moral exclusion that are taken to justify the treatment of those subjected to them.

In Section 3 and Section 4, I apply this analysis to the U.S. prison system. I argue that the U.S. prison system is a torturous institution in which direct torture occurs (the use of solitary confinement) and in which torture is allowed to occur (indirect torture) through the toleration of sexual assault of inmates and the conditions of mass incarceration. While the destructive effects of solitary confinement, sexual assault, and mass incarceration are well documented, conceptualizing the U.S. prison system as a torturous institution serves two important purposes. First, it highlights the severity of suffering and moral exclusion produced by institutional practices and conditions, where the true impact of such practices and conditions has been ignored, minimized, and even justified. Second, it enables us to see how the use and toleration of such torture is not accidental or the product of a few 'bad apples' but results from the long history of the U.S. prison system's function in enforcing the racialized moral exclusion of people of color, particularly African Americans, from the realm of equal moral consideration. While all inmates may be subject to torturous conditions, and while gender and sexual orientation also affect vulnerability to torture in the prison system, race operates as a distinctive moral 'marker' that dramatically increases a person's vulnerability to exposure to torturous 
prison conditions. As a result, the nature of the U.S. prison as a torturous institution, and the way in which people of color are disproportionately made vulnerable to torture in this system, "is fully intelligible only in this specific racial context” (Swartzer 2019, 15). Conceptualizing torture in terms of its experiential imprint thus not only provides an important tool for analyzing and understanding the torturous impact of the prison system, but also opens up the possibility that other social structures and practices not previously conceptualized as torture might also function as torturous institutions, a possibility I touch on in my conclusion.

\section{Experiencing and Defining Torture}

Rather than starting with a definition of torture and then applying that definition to different cases, I begin my analysis of torture by looking at the phenomenology of torture as derived from research on torture survivors and accounts of survivors of torture-accounts drawn on by a number of philosophers in developing conceptions of the distinctive moral wrongness of torture. ${ }^{2}$ Looking at the experiences of survivors of treatment that is unquestionably torture under any plausible definition allows us to see torture's distinctive experiential imprint, without making any a priori assumptions as to what other actions, practices, or conditions might constitute torture. These accounts, and the philosophical accounts that draw on them, reveal that the experience of torture is characterized by complete vulnerability to extreme suffering in the face of total domination, that can lead to the destruction of the basis of selfhood and the subsequent loss of moral trust in the world and oneself.

\subsection{The Experience of Torture: Vulnerability, Suffering, and Isolation}

Torture unquestionably involves the infliction of extreme suffering. ${ }^{3}$ What is clear from survivor accounts and research on torture survivors is that calculating the impact of torture primarily in terms of the severity of

\footnotetext{
2 See Bernstein 2015, Luban 2014, Scarry 1985, and Sussman 2005. For prominent accounts of torture by torture survivors, see Tillerman 1981 and Améry 1980.

${ }^{3}$ For example, the UN Convention Against Torture defines torture as follows:

For the purposes of this Convention, the term 'torture' means any act by which severe pain or suffering, whether physical or mental, is intentionally inflicted on a person for such purposes as obtaining from him or a third person information or a confession, punishing him for an act he or a third person has committed or is suspected of having committed, or intimidating or coercing him or a third person, or for any reason based on discrimination of any kind, when such pain or suffering is inflicted by or at the instigation of or with the consent or acquiescence of a public official or other person acting in an official capacity. It does not include pain or suffering arising only from, inherent in or incidental to lawful sanctions. (quoted in Betz 2006, 128)
} 
suffering misunderstands and underestimates the trauma of torture. For many torture survivors, it is not the experience of physical suffering itself that is the most traumatic aspect of torture, but the awareness of their total vulnerability to the infliction of such suffering and their isolation from any source of help. ${ }^{4}$ This point is emphasized in a number of philosophical accounts. Sanford Levinson, for example, describes torture as "less about concrete acts than about the creation of a phenomenological reality of total control" $(2007,151)$. Theimo Breyer argues that in torture, one person is "utterly dependent on the will and action of those in power" and forced to be aware of her complete vulnerability and her isolation from any source of help or comfort $(2017,742,744) .{ }^{5}$ It is these characteristics of torture that lead David Luban to describe torture as the purest form of a "totalitarian relationship" $(2014,134)$.

The radical isolation that is characteristic of the experience of torture is not limited to the duration of the torture but is compounded by the difficulty of communicating the experience of torture to others. As Jay Bernstein explains, a person's pain is "so emphatically inward in its primary significance that it becomes the exemplary instance of what can be doubted" $(2015,81)$. The problem of communicating the experience of suffering to others-and thus of being believed-is made even harder when a torture victim has no visible physical wounds from torture, as is often the case with so-called enhanced interrogation methods, such as solitary confinement and noise bombardment. ${ }^{6}$ Thus, torture victims may find themselves disbelieved not only by authorities but by members of their own community, further isolating them from sources of help, comfort, justice, and recognition.

\subsection{Destruction of Selfhood}

Torture violates, manipulates, and co-opts the victim's physical and emotional boundaries of selfhood in ways that can be almost impossible to repair. As Elaine Scarry explains, the torture victim's body “in its physical strengths, in its sensory powers, in its needs and wants . . . is, like the prisoner's voice, made a weapon against him, made to betray him on behalf of the enemy, made to be the enemy" $(1985,48)$. This is why David Sussman describes torture as a form of "forced self-betrayal" $(2005,4)$. One of the most significant and lasting effects of this experience of self-betrayal can be

\footnotetext{
${ }^{4}$ For example, a 2007 study of 279 torture survivors found that it was victims' distress and feelings of helplessness at the time of the torture that was most highly correlated with severe traumatic stress, and not the specific torture methods to which victims were subjected (Basoglu et al. 2007, 277).

${ }^{5}$ For some authors, this forced awareness of vulnerability and isolation lies at the heart of the moral wrong of torture. Breyer, for example, argues that the isolation of the torture victim "from all humanity" is "a form of radical violence" $(2017,744)$.

${ }^{6}$ Indeed, states engaging in torture often choose such torture methods precisely because they leave few physical marks, and thus undermine the victim's credibility. See Rejali 2007 for a discussion of the development of these forms of 'clean' torture.
} 
a loss of trust in one's self-one's emotions and basic bodily sensations such as pleasure have been made to serve the torturer's ends. As Susan Brison describes in her account of the impact of her violent rape, "My body was now perceived as an enemy, having betrayed my . . . trust and interest in it" $(2002,44)$.

In addition, survivor testimony and research on the effects of torture reveals how torture often undermines the physical, emotional, and cognitive bases of "concrete personhood" (Guenther 2013, 35)—the embodied sense of self that is grounded in our interactions with others and with the world. A torture survivor may experience "a diminished capacity to feel immediately and indubitably convinced about the reality of one's experiences" (Printzlau 2018, 211), which is connected to a loss of the ability to see the world (and experiences of the world) as fundamentally shared: "[a] sense of self is made possible-and real-alongside the sense of reality . . . Seeing something as real is seeing something as shareable, simultaneously present to me and to others" (Printzlau 2018, 214). ${ }^{7}$ This is why the loss of a sense of self that is common among torture survivors is often accompanied by "derealization (loss of the sense of reality)" (Breyer 2017, 747). As Lisa Guenther argues, the testimony of prisoners subjected to solitary confinement supports this account, showing how "the intersubjective basis for their concrete personhood, and for their experience of the world as real and objective, as irreducible to their own personal impressions, is structurally undermined by the prolonged deprivation of a concrete, everyday experience of other people" $(2013,35)$.

The impact of torture, therefore, cannot be understood without the recognition of the human self as embodied and intersubjective. It is only with such an understanding of human selfhood that we can see how torture undoes the very basis of selfhood and of shared reality, and why torture is therefore "a process of devastation" (Bernstein 2015, 77, 105-115). ${ }^{8}$

\subsection{Destruction of Moral Trust}

Contributing to the distinctive traumatic impact of torture is the victim's awareness that her helplessness and vulnerability is the product of human

\footnotetext{
${ }^{7}$ See also Guenther 2013, 167-181. I say more about solitary confinement in Section 3.

${ }^{8}$ The phenomenology of torture therefore challenges broadly Kantian conceptions of personhood that define personhood in terms of rational agency. In her discussion of Jean Améry's account of torture, Janna van Grunsven points out that "a self predominately understood as fundamentally a 'thinking substance' or 'rationally self-determined will,' who in his deepest or most 'dignified' core is pictured as undetermined by others and by bodily experience, cannot be permanently undone as the result of a violent attack by another on his body" $(2014,150)$. Guenther makes a similar point: "if we conceptualize persons as fundamentally autonomous agents, there would be no reason to expect a wholesale derangement of personhood in solitary confinement" (2013, xxviii). It is beyond the scope of this article to explore these implications in detail. See Bernstein 2015, 175-217, for a discussion of the implications of the phenomenology of torture for philosophical conceptions of human agency.
} 
agency; she is made helpless because others want her to be helpless and want her to know that she is helpless. She is forced to be constantly aware that the boundaries of her body and self may be violated at any moment. For several philosophers it is this message, communicated by the torturer to the victim through the acts of torture, that lies at the heart of torture's devastating impact. For example, Jay Bernstein (drawing on Jean Améry's searing account of his torture by the Nazi police) argues that the torture victim is forced to recognize her treatment as expressing a total rejection of her moral standing by the torturer: a declaration that there are no moral constraints on how she may be treated. Torture is therefore a moral injury (and not just an extreme form of physical injury); it is "the cancellation of one's mattering, and thus one's standing as human" $(2015,103)$.

David Luban shares the view that torture's distinctive moral harm lies in the message communicated to the victim by the torturer. Torture is the "assertion of unlimited power over absolute helplessness, communicated through the infliction of severe pain or suffering on the victim that the victim is meant to understand as the display of the torturer's limitless power and the victim's absolute helplessness" $(2014,110)$. The torturer's absolute power over the torture victim sends a message of "radical hierarchy and radical worthlessness" that is intended to be recognized as such by the torture victim $(2014,132)$. For Luban, it is this communicative aspect of torture that explains why torture is fundamentally "an act of humiliation" $(2014,135)$. Such humiliation "is not an incidental consequence of pain or suffering-it is the fundamental message that the pain and suffering of torture aim to convey" $(2014,135-136) .{ }^{9}$ Bernstein agrees, arguing that torture is "best understood as a radical version of the kind of devaluation or degradation at issue in experiences of humiliation" $(2015,124)$.

Torture thus represents a total denial of the moral recognition that we take for granted in our everyday lives-the belief that we matter, morally speaking, and that others recognize at least some constraints on how we may be treated (Bernstein 2015, 178-217; see also Wolfendale 2017).

Torture therefore can destroy our belief "that our mere being in the world matters to relevant others" (Bernstein 2015, 111) and devastate our capacity for basic moral trust. ${ }^{10}$ In Jean Améry's words:

\footnotetext{
${ }^{9}$ See Rijt 2016 for a critique of Luban's account of torture as humiliation.

${ }^{10}$ This loss of moral trust is common to survivors of other forms of interpersonal violence, such as rape (e.g., see Brison 2002). Note that I am not claiming that all torture survivors will experience this loss of moral trust and devastation of selfhood. The length of imprisonment, the environment in which torture occurs, the victim's level of education and prior psychological well-being, and the victim's access to support networks after release will all affect a torture victim's capacity to recover. However, this does not change the fact that torture has the potential to devastate a victim's capacity for moral trust and, as evidenced by the experiences of many torture survivors, often does have the long-term devastating effects described above. Just as we would not revise our judgment of the severity of an act of rape in light of a victim's capacity to recover, so we should not revise our judgment of the devastating nature of torture
} 
Whoever has succumbed to torture can no longer feel at home in the world. . . . Trust in the world, which already collapsed in part at the first blow, but in the end, under torture, fully, will not be regained. That one's fellow man was experienced as the antiman [the torturer] remains in the tortured person as accumulated horror. It blocks the view of the world in which the principle of hope rules. $(1980,40)$

\section{An Experiential Definition of Torture}

The preceding discussion of the phenomenology of torture reveals how devastating the impact of torture can be; the profound and lasting effects of complete vulnerability to domination and suffering can lead to the destruction of selfhood and the radical loss of trust in the world and oneself. From this brief discussion, I propose the following experiential definition of torture:

Torture is the experience of complete vulnerability to extreme suffering in a context of domination, where the experience of vulnerability reinforces and expresses the torture victim's moral exclusion from equal moral consideration.

This definition is not intended to serve the purposes of a legal definition of torture. Rather, this definition is intended to capture the moral and experiential distinctiveness of torture from the victim's point of view, as derived from the accounts of torture survivors. Consistent with standard definitions, my proposed definition includes reference to extreme suffering, but also incorporates the insights offered by Luban, Bernstein, and others that highlight the function of torture in expressing moral exclusion or degradation in a context of domination. ${ }^{11}$ However, my definition makes no reference to perpetrators' intentions, nor to any specific purposes for which torture might be used, such as coercing a confession or as punishment. Put simply, there is no torturer in my definition of torture.

My account therefore departs significantly from legal definitions such as that in the Convention Against Torture, and the philosophical accounts of torture discussed above, in which the dynamics of torture are characterized almost entirely in terms of the interpersonal relationship between torturer and victim. For example, Bernstein defines torture as "a relation between

in light of the fact that some victims may recover more than others, or in light of the fact that some cases of torture may be less severe than others.

11 Thus, my definition is not purely subjective. While it is possible, in theory at least, that a person could experience the impact of torture without having been tortured (e.g., because they suffer from delusions of torture), because my proposed definition makes reference to the context in which torture occurs, it would be possible to evaluate objectively whether or not a person was made vulnerable to suffering in a context of domination. 
two individuals" $(2015,78)$ in which the distinctive moral harm of torture is “essentially related to one person's intentional injury of another" (2015, 122). Likewise, Luban places primary importance on the relationship between torturer and victim, and the meaning conveyed to the victim through the torturer's actions. This conception of torture as relational and intentional is shared by other authors. Jan-Willem van der Rijt writes, for example, "[b]y necessity, torture involves a victim, the tortured, and someone who inflicts the torture, the torturer. . . . Torture is relational in nature" $(2016,482)$. For these authors, it is the intimate relationship between torturer and victim, and the specific dynamics of that relationship, that constitute the nature of torture and help to explain the devastating impact of torture on torture victims. ${ }^{12}$

While these accounts offer insightful and important contributions to our understanding of torture, I argue that the concept of torture is broader than these accounts acknowledge. As I demonstrate in Section 3 and Section 4, institutional and social practices can create the experience of torture in those subjected to them, in the absence of an interpersonal relationship between a torturer and a victim, and thus in contexts where no individual person intends to commit acts of torture. ${ }^{13}$ Thus, while I agree with Luban and Bernstein that torture necessarily involves domination and the creation of complete vulnerability to suffering that communicates a message of "radical worthlessness" to the torture victim, this message does not require an individual messenger. To see this first requires looking more closely at the role that intention plays in standard accounts of torture.

\subsection{Intention in Standard Accounts of Torture}

Intention in a definition of torture can be broadly or narrowly construed. David Luban's account of intention is an example of the former. In his view, for an act to constitute torture it must be performed knowingly and

\footnotetext{
${ }^{12}$ I am not denying that many real cases of torture $d o$ involve torturers acting intentionally, and Luban's and Bernstein's accounts provide important insights into the dynamics of such forms of interpersonal torture. Rather, I am arguing that torture can occur even in the absence of an interpersonal relationship between torturer and victim.

${ }^{13}$ It might also be possible, on my account, to conceive of torture as relational in a broad sense since within torturous institutions (as I shall argue) individual agents are acting within a web of structural and institutional relations that express and reinforce narratives of moral exclusion that structure the relationships of individual actors to the institution and to those subjected to the institution. Additionally, it might be objected that even in the absence of a direct interpersonal relationship between torturer and victim, a victim may still feel as if she were at the mercy of a hostile 'other.' In that sense, torture might still be thought to necessarily involve a kind of interpersonal relationship. However, even if we want to describe this feeling as a kind of interpersonal relationship (which is not obvious), this is not the kind of interpersonal relationship that Luban and others see as characteristic of torture. Furthermore, I see no reason to posit the existence of even this attenuated form of an interpersonal relationship as part of the very definition of torture. I thank Theresa Tobin and an anonymous referee for raising these concerns.
} 
purposively (see Hresko 2006, 23). Unlike a surgeon who knows she inflicts pain on her patient but does not aim at doing so, a torturer knows that her actions cause severe pain and causing severe pain is what she aims to bring about: "the pain-infliction is not merely an unwanted byproduct of the torturer's actions. There are no accidental waterboarders" (Luban 2014, 113-114). However, to meet this conception of intention, she need not consciously conceive of her actions as torture or have a specific purpose in mind (such as getting a prisoner to reveal information).

Examples of narrow definitions of intention are found both in Eighth Amendment jurisprudence ${ }^{14}$ and in the infamous 'torture memos' produced by the Office of Legal Counsel for the Bush Administration during the years following 9/11. After the 1970s, a number of federal and Supreme Court judgments on Eighth Amendment cases argued that, for a prison practice or policy to violate the Eighth Amendment, it must be shown that prison officials had a "wrongful subjective intention" ("Complex Enforcement" 1981, 626). ${ }^{15}$ Thus, even if prison conditions (e.g., overcrowding) or prison practices are found to cause severe suffering to prisoners, "[c]ruelty in violation of the Constitution must depend on the intentions of those who punish and not on the physical act of punishment or the impact on the prisoner being punished" (Dayan 2001, 26). If prison officials do not have "malicious intent" (Dayan 2001, 33), their actions do not constitute acts of cruelty no matter how much harm they cause the prisoners subjected to them. ${ }^{16}$

${ }^{14}$ It may seem odd to talk about Eighth Amendment cases as involving torture, since the Eighth Amendment refers to cruel and unusual punishment, not torture. This is result of the fact that in U.S. domestic law there is "no single provision of the U.S. Constitution [that] expressly prohibits torture as a means to extract information, secure a confession, punish for an act committed, intimidate or coerce, or for any reason based on discrimination." (Human Rights Watch 2004). Instead,

The U.S. courts have located constitutional protections against interrogations under torture in the Fourth Amendment's right to be free of unreasonable search or seizure (which encompasses the right not be abused by the police), the Fifth Amendment's right against self-incrimination (which encompasses the right to remain silent during interrogations), the Fifth and the Fourteenth Amendments' guarantees of due process (ensuring fundamental fairness in criminal justice system), and the Eighth Amendment's right to be free of cruel or unusual punishment. (Human Rights Watch 2004)

${ }^{15}$ As Dayan illustrates, in the case Wilson v. Seiter (1991): "The Supreme Court ultimately required a separate subjective component for all Eighth Amendment challenges to prison practices and policies" $((2001,26))$.

${ }^{16}$ Justice Clarence Thomas used similar reasoning in the 2019 death penalty case Bucklew v. Precythe, arguing that the Eighth Amendment "bars only the intentional infliction of pain . . . and there was no evidence that Missouri had designed its lethal injection protocol to hurt Mr. Bucklew" (Liptak 2019). Bucklew was a prisoner on death row with a rare medical condition that meant the execution method of lethal injection would likely cause him to "drown in his own blood" (Epps 2019). 
The Office of Legal Counsel explicitly drew on this Eighth Amendment jurisprudence to argue for a narrow interpretation of intention in the definition of torture (Dayan 2007, 61-62). The August 1, 2002, memo on the "Standards of Conduct for Interrogation" states that:

a defendant is guilty of torture only if he acts with the express intention of inflicting severe pain or suffering on a person within his custody or physical control. . . . Further, a showing that an individual acted with a good faith belief that his conduct would not produce the result that the law prohibits negates specific intent. . . . Where a defendant acts in good faith, he acts with an honest belief that he has not engaged in the proscribed conduct. (Cole 2009, 45-46, emphasis added)

Thus, "even if the defendant knows that severe pain will result from his actions, if causing such harm is not his objective, he lacks the specific requisite intent" (Cole 2009, 45). In this account, an agent must consciously intend to commit acts of torture (not just acts that inflict pain) to legally be a torturer. So, if she honestly believes that the pain she inflicts does not amount to torture then, according to the above interpretation, she is not inflicting torture no matter how much her victim suffers and even if she intends to cause this suffering.

\subsection{Torture Without Intention}

There are good reasons to reject the narrow definition of intention. First, the "good faith belief" clause in the August 2002 memo effectively makes it impossible to prove that an accused interrogator committed torture (no doubt one of the intentions of the memo's authors). Likewise, the requirement of subjective malicious intent in the Eighth Amendment cases mentioned earlier sets an "impossibly high bar for Eighth Amendment violations" (Dayan 2007, 32), because it is next to impossible to prove that a prison official had "malicious intent" or that prison conditions that are causing extreme suffering to prisoners are the result of any individual person's intention to treat prisoners cruelly.

More problematically, by focusing on the torturer's subjective state as determinative of whether torture has occurred, these definitions deemphasize the victim's subjective state. If the torturer lacks the specific intention required by these definitions, then the victim is not experiencing torture no matter how much she suffers. As Dayan notes in relation to Eighth Amendment decisions that require subjective intent: "The Court's logic thus strips the victim of the right to experience suffering, to know fear and anguish. . . . Subjectivity is the privilege of those in control" (Dayan 2001, 26-27). Thus, it is the torturer's state of mind that determines whether torture occurs, and not what is done to the victim. This approach 
represents an extraordinary privileging of the perpetrator's perspective at the expense of the victim's. We thus have good reason to reject the narrow conception of intention.

Yet, while Luban's broader conception of intention does not privilege the perpetrator's perspective to the same degree as the narrower conception, defining torture in terms of an interpersonal relationship in which the torturer intends to inflict suffering artificially narrows our understanding of when and how torture occurs. ${ }^{17}$ In Section 1, I showed how the experiential imprint of torture is characterized by complete vulnerability to extreme suffering in a context of domination, which can (and often does) lead to a devastating loss of self and moral trust in the world. I argue that we should think of torture in terms of the conditions, practices, and actions that create that experiential imprint, and not primarily in terms of the states of mind of those involved in causing those effects. This conception of torture allows us to see how conditions, actions, institutions, and practices can create the effects of torture in a broader range of cases than standard views allow.

An analogy with debates about the definition of racism helps to illuminate my approach here. If racism is defined solely "in terms of [the] belief, behavior, volition[s]" of individual persons, it becomes impossible to make sense of the plausible intuition that a practice or institution could be racist even if "no one involved . . . holds any racist attitudes or beliefs" (Pierce 2014, 26). ${ }^{18}$ Racism can be thought of in individual terms or in "structural or institutional terms, as a system of power that disadvantages some to the benefit of others" (Pierce 2014, 23, emphasis original). But to make sense of the possibility of institutional racism requires defining racism in terms of its effects rather than in terms of the mental states of those who bring those effects about. For example, Andrew Pierce argues that:

institutional racism is better understood as . . . a systematically related set of distributive injustices, producing systematic advantage or disadvantage depending on one's race. To say that the distributive injustices are systematically related means that they are, if not interdependent, at least mutually supporting in ways that dispose those

\footnotetext{
${ }^{17}$ I accept that this conception of intention may be important for the purposes of establishing legal culpability, however. By referring to the absence of torturers, I am not claiming that no individuals bear moral responsibility for the practices that create torturous conditions.

${ }^{18}$ For example, mortgage policies that privilege those with good credit (based, for instance, on asset ownership and debt history) may not be explicitly discriminatory. Yet, the implementation of these policies systemically disadvantages African Americans because of the ongoing effects of prior explicit forms of discrimination. For example, the practice of redlining denied African Americans the ability to own homes and disincentivized development in African American-majority neighborhoods. This resulted in an ongoing significant wealth gap between white and African American households and thus lower credit scores for African Americans (Costa 2019). Now, one might argue that the individuals who implement these practices are in fact motivated by racist beliefs. That may or may not be true, but the point here is that it makes sense to talk about these practices as racist even if no one involved holds racist beliefs.
} 
who suffer from one to suffer from others as well. . . . Institutional racism of this kind does not depend upon the ongoing intentional malice of racist agents. . . . This is why institutional racism can occur in the absence of individual racism. $(2014,32,33) .{ }^{19}$

Articulating the concept of race in terms of its effects thus enables a better understanding of the impact, nature, and scope of racism on those most affected by it, and arguably offers a more productive approach to thinking about how to fight racism. ${ }^{20}$ Similarly, defining torture in terms of its distinctive experiential imprint and function (and not primarily in terms of perpetrators' states of mind) allows us to consider the possibility of institutional or structural forms of torture and opens up new avenues for thinking about how to combat torture. ${ }^{21}$

Two objections can be raised at this point. First, it might be argued that, in the case of institutional racism, we should attribute racist intentions to the institution in question, even if that intention is not reducible to the intentions of agents acting within the institution. By analogy, rather than arguing that torture can occur without intention, we should consider the possibility that an institution that creates torturous effects (e.g., the prison system) possesses an institutional intention to torture. This possibility would retain the intuition that torture is an intentional act without implying that every (or indeed any) agent involved in the institution intends to commit acts of torture. Second, it can be objected that my proposed definition of torture is too broad, leading to institutions, practices, actions, or conditions being labeled as torture in ways that far exceed common understandings of the term, thereby diluting the normative significance of the word. ${ }^{22}$ I address each of these objections in the following sections.

\footnotetext{
${ }^{19}$ Kate Manne takes a similar approach in her account of misogyny. She rejects definitions of misogyny that define it in terms of mental states such as hatred of women and argues for a definition of misogyny based on its function- "imposing social costs on noncompliant women" $(2016,6)$. What makes a person's behavior misogynist is not their beliefs, emotions, or intentions, but the effect of their behavior on women subjected to it. This is, of course, consistent with the claim that some people who behave misogynistically are also motivated by hatred of women.

${ }^{20}$ For example, it is may be difficult if not impossible to prove that a person's motivations are racist, but it is possible to track the effects of policies or practices that disproportionately cause harm to people of color.

${ }^{21}$ By being agnostic as to the states of minds of those involved in creating torturous conditions, my account does not imply anything about the moral character of those involved. My view would be consistent with the claim that a person who does intend to inflict torture is morally worse than one who participates in a torturous institution but does not intend torture. However, judgments about the moral character of agents involved in creating the conditions of torture are not relevant to judgments about whether a set of conditions consitute torture. 22 I thank two anonymous referees for raising these objections.
} 


\subsection{Is There an Institutional Intention to Torture?}

Institutions and institutional practices are the result of highly complex relationships between the actions (and inactions) of many individuals acting collectively. For example, the development of a supermax prison at a specific location is the result of a set of complex interactions between voters who elect 'tough on crime' legislators, political support for a supermax prison, economic factors that favor a particular location for the prison, architects who build the prison and design its solitary confinement cells, prison officials who operate the prison, individual prison guards who work in the facility, and even the media who depicts those to be imprisoned within the supermax as the 'worst of the worst.' What would it mean to attribute a single intention to this set of interactions or to the institutions involved?

First, it is far from clear that we can even identify a single institution to which an intention to torture could be assigned. (Is it the prison? The state? The criminal justice system?) Attempting to locate a single institutional 'intention' is not only probably impossible; it also fails to capture the complexity and mutually reinforcing nature of the causal relationships between the practices, actions, policies, and conditions that combine to produce something like a prison system.

Second, to argue for the existence of an institutional intention (not reducible to the intentions of individual actors) to 're-insert' intention into the definition of torture requires a commitment to a controversial view about collective intentionality. ${ }^{23}$ Rather than attempting to defend such a view-a task well beyond the scope of this article-we should ask what we would gain by arguing for the existence of an institutional intention to torture. I suggest that we gain very little in our understanding of torture from adopting this view. Just as we can talk about structural racism in terms of the effects of institutional practices (without assuming or positing the existence of an institutional intention to be racist), so can we talk about institutional or structural torture without making any claims about the intentions of those involved and without attributing mental states to the institution itself.

\subsection{Broadening the Definition of Torture}

Defining torture without intention, as I do, raises the possibility that conditions such as poverty should be labeled a form of torture. After all, poverty can cause many of the effects that I attribute to torture, such as vulnerability to suffering, destruction of selfhood, and loss of moral trust in the world. But to call poverty 'torture' goes beyond any common-sense understandings of the term. Similar concerns might be raised by the application of my

\footnotetext{
${ }^{23}$ See Jankovic and Ludwig 2018 for an overview of this debate.
} 
definition to other cases, such as vulnerability to the extreme effects of climate change.

I have three responses to this objection. First, I agree that it would be a problem with my view if the term 'torture' were to lose its normative significance. Torture represents a distinct and severe moral harm. However, my definition retains the moral significance of torture by making explicit reference to vulnerability to extreme suffering through relations of domination in a context of moral exclusion. Many cases of poverty will not meet this definition, because poverty does not always cause extreme suffering and because not all cases of vulnerability to suffering (whether through poverty or other natural or human-caused conditions, such as war, epidemics, and natural disasters) are expressive of moral exclusion or come about through relations of domination. However, if poverty in a particular case is severe enough to cause the effects that are characteristic of torture and does so through institutional structures, practices, and conditions that are expressive of domination and moral exclusion (e.g., through exclusionary housing policies, structural lack of access to clean food and a clean environment, lack of access to healthcare, and greater vulnerability to violence), then I argue we should call such cases instances of torture. Describing such cases as torture, far from diluting the significance of the term, is an important way of marking and recognizing the severity of the suffering caused and the ways in which that suffering can be expressive of moral exclusion and relationships of domination.

Second, it's important to understand that our intuitions about what counts as torture are not value-neutral but reflect pre-existing assumptions about the nature of suffering and about what kinds of suffering matter. ${ }^{24}$ For example, the supposed distinction between torture and 'torture lite' is based on the (false) assumption that torture methods that are not physically violent are less severe or harmful than physically violent methods (Wolfendale 2009). So, we have reason to be wary of relying on our intuitions about which forms of suffering amount to torture. We should be particularly wary of our intuitions about what constitutes torture when considering conditions or practices that disproportionately cause suffering to people of color. For example, it is well documented that in medical contexts the pain of African Americans is treated as less severe and more likely to be dismissed than the reported pain of white people (Hoffman

\footnotetext{
${ }^{24}$ For example, an anonymous reviewer suggested that cases of torture in ticking bomb situations would not be likely to produce the severe effects that I argue are characteristic of torture. But, as I noted in footnote 10, I am not claiming that all cases of torture will produce the same effects on all torture victims. Rather, torture is likely to (and often does) have the effects I discuss. More importantly, the assumption that a single instance of torture is not likely to have serious long-term effects reflects an unstated (and unsupported) assumption that only 'really bad' or prolonged torture results in long-term harm. But we have no reason to assume this is the case. Indeed, the experiences of survivors of acts like rape, such as Susan Brison, show that a 'single instance' can be extremely devastating. This is further reason why we should be wary of our intuitions regarding what does and does not constitute torture.
} 
et al. 2016). This dismissal of the pain of African Americans can be traced to myths about biological differences between African Americans and white people that originated during slavery to justify and minimize the suffering of enslaved African Americans and that persist to this day. ${ }^{25}$ As a result, when considering situations that disproportionately affect African Americans and other people of color such as incarceration or poverty, it is likely that intuitions about the severity of the suffering caused by these conditions will be shaped by these long-standing and largely unarticulated racist beliefs. In such cases, far from clarifying our conception of torture, deferring to ordinary usage or common-sense understandings of torture is likely to reinforce such beliefs.

As Andrew Pierce argues in defending his account of structural racism from a similar charge, arguing that we should adhere to common-sense conceptions of racism can "discourage using the term in non-typical ways that nonetheless might illuminate important features of social reality" (2014, 35). Similarly, deferring to common understandings of torture in deciding what does and does not count as torture inhibits recognition of the ways in which such understandings are shaped by and reflect biased assumptions about what counts as suffering and whose suffering counts. Adopting a non-intentional account of torture allows us to see that, just as there can be institutional or structural racism, so there can be institutional and structural torture. In what follows, I argue that the U.S. prison system is such an institution.

\section{Prison as a Torturous Institution}

A torturous institution is not simply an institution in which acts of torture occur. Instead, a torturous institution is one in which those subjected to that institution are made vulnerable to experiences of torture and in which the acceptance of torturous conditions is sustained by narratives of moral exclusion that are taken to justify the treatment of such individuals. Understanding how and why torture occurs in such an institution requires understanding how the use and acceptance of torture is made possible (and made sense of) in light of background ideologies of moral exclusion that shape the meaning, operation, and justification of the institution.

${ }^{25}$ Hoffman et al. document how

in the 19th century, prominent physicians sought to establish the 'physical peculiarities' of blacks that could 'serve to distinguish him from the white man'. . . Such 'peculiarities' included thicker skulls, less sensitive nervous systems, and diseases inherent in dark skin. . . . Dr. Samuel Cartright, for instance, wrote that blacks bore a 'Negro disease [making them] insensible to pain when subjected to punishment'. . . . Other physicians believed that blacks could tolerate surgical operations with little, if any, pain at all. $(2016,4296)$ 
Slavery is a paradigmatic torturous institution. The institution of slavery is defined by the complete domination of one group by another, where those who are enslaved are deemed to be morally open to such domination and thus morally excluded from full moral recognition, ${ }^{26}$ and where such exclusion is justified through social and political narratives of racialized moral difference. The nature of the institution of slavery creates the conditions of complete vulnerability to extreme suffering that are one of the defining features of torture, as I argued in Section 1 . Thus, even relatively well-treated enslaved persons are still utterly vulnerable to the desires and whims of their owners and are made fully aware of that vulnerability. As Philip Pettit explains, "slavery is essentially characterized by domination, not by actual interference: even if the slave's master proves entirely benign and permissive, he or she continues to dominate the slave" (1997, 31-32). But to see how the institution of slavery creates the conditions of torture requires recognizing how white supremacist ideology provided the exclusionary narratives evoking supposed racial differences that justified the fitness of enslaved persons for torturous treatment and that were codified in law (see Stone-Mediatore 2019, 546; Dayan 2011, 50-51). Such narratives also served to deny that such treatment is torture, as we saw in Section 2.4 in relation to attitudes toward the suffering of African Americans.

Prison, however, does not initially appear to be a torturous institution. The institution of prison exists in many forms, in many countries, and is not (as slavery is) necessarily defined by a relationship of domination and moral exclusion of one group by another. However, the prison system in its current form in the United States is a torturous institution; it is an institution in which both acts of direct and indirect torture occur, and in which the use and toleration of both forms of torture expresses and reinforces a system of domination, control, and moral exclusion that has its origins in slavery, the convict lease system, and segregation. ${ }^{27}$ As with slavery, it is impossible to understand how and why the prison system creates torturous conditions, and who is made disproportionately vulnerable to torture within the system, without understanding the ways in which the U.S. criminal justice system as a whole is "systematically biased against people of color . . . American policing and penal practices grew out of previous forms of racial control and . . U.S. criminal justice reinforces racial hierarchies" (Swartzer 2019, 1).

\footnotetext{
${ }^{26}$ That slavery is an institution of complete domination is made explicit in a number of nineteenth century court judgments relating to the treatment of slaves. For example, in State $v$. Mann (1829), the North Carolina Supreme Court overturned the conviction of John Mann for the assault and battery of his slave, Lydia, on the grounds that "inherent in the relation of master and slave' was the fact that 'the power of the master must be absolute to render the submission of the slave perfect.' . . . hard discipline 'belongs to the state of slavery' . . Violence ... 'is inherent in the relation of master to slave"” (Morris 1996, 190).

27 See Alexander 2011, Guenther 2013, 39-61, Dayan 2011, and Muhammad 2010 for detailed accounts of the historical connections between slavery, the convict lease system, segregation, and the modern criminal justice system.
} 


\subsection{Direct and Indirect Torture in U.S. Prisons}

It is not difficult to make the case that acts of torture occur within the U.S. prison system. Direct torture occurs because solitary confinement is deliberately used on a significant number of inmates. Indirect torture occurs because the conditions of imprisonment, exacerbated by mass incarceration, make inmates vulnerable to torturous experiences including rape, sexual assault, and the deprivation of basic needs such as decent food, warmth, and shelter, and connections to family and friends. In the following sections, I make the case for why these practices count as torture, before showing how such practices make sense only within a conceptualization of the prison system as a system of racialized moral exclusion.

\subsubsection{Solitary Confinement}

Rough estimates from surveys and prison data suggest that at least 60,000 people are held in solitary confinement at any given time (SolitaryWatch 2018), a figure that does not include those held in solitary confinement in immigration detention centers. ${ }^{28}$ Of those in solitary confinement, approximately 20,000 are held in long-term solitary confinement (Reiter 2014, 458).

Solitary confinement cells exist in many jails and prisons, but supermax prisons are explicitly designed to house inmates in solitary confinement. Such prisons represent the "large scale use of extended isolation as a 'concentration' strategy . . . states 'concentrate' the putatively 'worst of the worst' inmates in one place” (Mears 2013, 683; see also Guenther 2013, 162). Mirroring the rise of mass incarceration, the number of supermax prisons has grown dramatically since 1986, from one in Arizona to at least one in 44 states in 2005, each holding approximately 25,000 inmates (Reiter 2014, 458). ${ }^{29}$

Solitary confinement cells are designed not merely to isolate some prisoners from others, but to create an experience of sensory deprivation (most lack windows or have small windows that offer no view, for example) and "extremely minimal human contact" (Hresko 2006, 5). Some prisoners in solitary confinement "can go for years, even decades, without experiencing any form of human touch beyond the chaining and unchaining of wrists through the cuffport in the door" (Guenther 2013, 64). Interactions with guards are either entirely non-physical or violently physically invasive, such as when random body cavity searches occur (Guenther 2013, 64). All other human contact (even with medical personnel) is conducted as much

\footnotetext{
${ }^{28}$ The use of solitary confinement is on the rise in immigrant detention centers (Wolfe 2019). According to one report, up to 40 percent of detainees in solitary confinement have a mental illness (Woodman and Saleh 2019).

${ }^{29}$ This figure is only an estimate, however, because there is "no unequivocal agreed-upon census of supermax inmates" (Mears 2013, 684).
} 
as possible via telelink or video to further minimize human interaction (Hresko 2006, 8-10).

The use of solitary confinement is often justified in terms of management, protection, and control rather than in terms of punishment: "according to prison administrators, supermaxes do not inflict violence; rather they contain and control violence" (Reiter 2014, 259). The names given to solitary confinement cells within prisons highlight this language of control and administration: "Special Housing Unit or Security Housing Unit (SHU), Control Unit (CU), Special Control Unit (SCU), Administrative Segregation Unit (ASU or Ad-Seg), Administrative Maximum Facility (ADX or Ad-Max), Intensive Management Unit (IMU), and even Communication Management Unit (CMU)" (Guenther 2013, 161). The language of management, protection, and control assists with the perception of solitary confinement as a necessary form of prison management, even protection, and not a brutal punishment or a form of violence.

Despite the innocuous-sounding language of control and protection that dominates the discourse of solitary confinement within the prison system, solitary confinement has devastating effects on those subjected to it, even for relatively short periods of time. Lisa Guenther, who conducted extensive research on inmates in supermax prisons, describes inmates' experiences of solitary confinement as follows:

Many prisoners speak of their experience in supermax prison as a form of living death. ... a meaningful sense of living embodiment has for the most part drained out their lives; they've become unhinged from the world, confined to a space in which all they can do is turn around or pace back and forth, blocked from an open-ended perception of the world as a space of mutual belonging and interaction with others. (Guenther 2013, 165)

Since the 1980s, studies on the effects of solitary confinement have found that solitary confinement results in a constellation of severe physical and psychological effects collectively known as "SHU syndrome," including intense anxiety, hallucinations, cognitive difficulties, hypersensitivity, violent fantasies, and poor impulse control (Hresko 2006, 11-12). ${ }^{30}$

These effects were evident from the earliest days of the use of solitary confinement: "In their 1833 report on the U.S. penitentiary system, Gustave de Beaumont and Alexis de Tocqueville observed that . . . 'absolute solitude, if nothing interrupts it, is beyond the strength of man; it destroys the criminal without intermission and without pity; it does not reform, it kills"” (Guenther 2013, 15). When Charles Dickens toured the infamous

\footnotetext{
${ }^{30}$ See also Guenther 2013, 36-38, and 161-194, and Reiter 2014, 469-471. Dayan notes that through self-mutilation prisoners become the vehicle of their own physical torture: "The inmates have reenacted the law's process of decreation on their own bodies, making visible what the law masks" $(2001,27-28)$.
} 
Eastern State Penitentiary in Philadelphia, he noted of prisoners in solitary confinement that their "very capacity to see and hear clearly and to make sense of their perceptions was radically diminished" (Guenther 2013, 19). Their faces "took on 'something of the strained attention which we see on the faces of the blind and deaf, mingled with a kind of horror, as though they had been secretly terrified" (Guenther 2013, 19). In light of what he witnessed, Dickens wrote, "I hold this slow and daily tampering with the mysteries of the brain, to be immeasurably worse than any torture of the body" (Guenther 2013, 18). Such reports even influenced the Supreme Court, who in the 1890 case In Re Medley "struck down the validity of solitary confinement, observing that it had a horrific capacity to inflict mental illness and despair" (Hresko 2006, 6). ${ }^{31}$

\subsubsection{Indirect Torture: Sexual Assault and Mass Incarceration}

Solitary confinement is a direct form of torture used against many inmates in U.S. prisons and jails. However, many inmates are vulnerable to torturous experiences that are not part of institutional policy or design-what I refer to as indirect torture. For example, according to a 2013 Bureau of Justice Statistics report, approximately 200,000 people held in U.S. prisons and jails face sexual abuse every year (Beck et al. 2013). Sexual assault (perpetrated by inmates against other inmates, and by guards against inmates) is so common that it is taken for granted-prison rape is the subject of jokes and threats by police officers and is regularly mentioned in popular culture depictions of prison (Feministo 2016), and victims of prison sexual assault are often disbelieved, demeaned, ignored, and mocked (Feministo 2016; Yurcaba 2018). ${ }^{32}$ Rape and other forms of sexual violence are acts of torture because such acts involve the extreme violation of the victim's self and the radical denial of the victim's moral standing that are characteristic of other forms of torture (see Bernstein 2015, 116-161). As I shall argue, mass incarceration exacerbates inmates' vulnerability to both sexual assault and other torturous prison conditions related to housing, food, denial of human contact, and access to health care.

These conditions have been the subject of recent prison protests, such as those by inmates in the Georgia State prison system in 2010, and were the basis of lawsuits and protests during the 1960s and 1970s (Dayan 2007; Reiter 2012). Inmates at Georgia State demanded "a living wage, access to educational opportunities and vocational training, better food and living conditions, better health care, greater access to families and loved ones, and an end to cruel and unusual punishment" (Guenther 2013, 126). More

\footnotetext{
31 According to Guenther, this court decision led to a decrease in the use of solitary confinement in U.S. prisons "until the introduction of behavior modification programs under the guise of 'treatment' in the 1960s and '70s" (Guenther 2013, 129).

32 In much the same way women who report sexual assault are rarely believed and are often held responsible for their attacks (see Harding 2015).
} 
recently, Brooklyn jail inmates protested the lack of heat, hot power, and power during the extreme cold of the polar vortex in early 2019 (Wang 2019). ${ }^{33}$ Taken individually, the prison conditions that are the subject of these demands do not seem to amount to torture. Lack of educational opportunities, for example, may be wrong for a variety of reasons, but it is not torturous. But to look at each condition in isolation ignores the fact that it is the combined effect of these forms of systematic neglect of inmates' basic emotional, physical, and relational needs that creates the conditions of torture, and that communicates the message of moral exclusion that defines the U.S. prison system as a torturous institution. Just as we cannot see the true impact of oppression unless we recognize how individual experiences of oppression are structurally related to create the "birdcage" of oppression (Frye 1983), so we cannot see the torturous effects of the prison system if we look at prison conditions in isolation from each other. To understand how inmates are made vulnerable to torture requires recognizing how these practices intersect to create the experience of torture, and how vulnerability to these experiences is affected by categories of moral exclusion, in particular that of race.

For example, the combination of a lack of ready access to medical care with a lack of proper heating in winter and air conditioning in summer, exposure to violence and sexual assault, and draconian restrictions on communication with friends and family leaves inmates highly vulnerable to severe pain and suffering, yet it simultaneously isolates them from relational sources of comfort and aid (Dixon 2010). ${ }^{34}$ This vulnerability to suffering combined with isolation (and the forced awareness of such isolation) is, as we saw in Section 1, characteristic of the experience of torture.

Mass incarceration exacerbates this vulnerability to torture and creates new vulnerabilities. Overcrowding greatly increases the vulnerability of inmates to torturous experiences resulting from exposure to physical violence, lack of medical care, deprivation of decent food, lack of heat and

\footnotetext{
${ }^{33}$ According the Guenther, the fact that "so little [has] changed in U.S. prisoners' demands in the forty years since the 1970s" despite many other changes to the U.S. prison system suggests that something is amiss in the humanist approaches to prisoners' rights that have dominated legal challenges to prison conditions (Guenther 2013, 125-157).

${ }^{34}$ Interestingly, prior to the late 1970s, a number of federal and Supreme Court judgments in Eighth Amendment cases recognized that systemic problems, such as inadequate staffing, failures to protect prisoners from violence, and lack of medical access, could combine to create unconstitutional conditions that "shocked the conscience," independently of the intentions of individual prison officials. Some judges acknowledged that recognizing how prison systems as a whole could create torturous conditions "may even result in a questioning of the very institution of punishment" ("Complex Enforcement" 1981, 637). A judge in the 1981 case Ramos $v$. Lamm wrote: "I am persuaded that the institution of prison probably must end. It many respects it is intolerable within the United States as was the institution of slavery, equally brutalizing to all involved, equally toxic to the social system, equally subversive of the brotherhood of man, even more costly by some standards, and probably less rational" (“Complex Enforcement” 1981, 637, n.79).
} 
air conditioning, and denial of access to close personal relations. Additionally, as Guenther argues, severe overcrowding also creates a "forced relationality" through the restriction of space and forced proximity to other inmates. Like solitary confinement, close confinement creates conditions that "do not allow for a mixture of contact and withdrawal in relation to other living beings in a shared but open-ended space" (Guenther 2013, 153). In such conditions, inmates are both isolated from each other (due to restrictions on communications) yet cannot escape into solitude nor choose the terms of engagement with other inmates. This structural undermining of "the network of relations with other living and nonliving beings that helps sustain a meaningful sense of Being-in-the-word" (Guenther 2013, 147) causes many of the same symptoms in inmates as those caused by solitary confinement, including "increased aggression, violence, and selfmutilation," (Guenther 2013, 152) and thus should also be understood as a form of torture.

\section{Moral Exclusion, Race, and the Function of the U.S. Prison System}

The destructive effects of solitary confinement, mass incarceration, and sexual violence in prison are well documented, and no reputable academic or politician seriously defends these practices. It might be objected, then, that by presenting the evidence for these destructive effects, I am simply stating the obvious. ${ }^{35}$ As I noted previously, it is not difficult to make the case that solitary confinement, for example, is a form of torture. But this raises an important question: Since the existence of torture in U.S. prisons is so well documented, why, despite the efforts of protest groups, is there so little public outcry about the fact that thousands of inmates are tortured within the U.S. prison system every year? Why, despite decades of research and centuries of first-person testimony documenting the devastating impact of solitary confinement, have federal courts and the Supreme Court refused to find solitary confinement per se a constitutional violation (Dayan

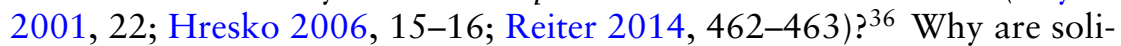
tary confinement, prison sexual assault, and the conditions resulting from

\footnotetext{
${ }^{35}$ I thank two anonymous referees for raising this concern. An additional objection to my discussion is that at least some of the practices I discuss do not amount to torture. I disagree. Given the distinctive experiential imprint of torture outlined in Section 1-derived from the experiences of survivors of treatment that uncontroversially meets standard definitions of torture-if the combination of the conditions discussed in Section 3 (overcrowding, denial of contact with friends and family, vulnerability to violence and sexual assault, and exposure to heat and cold) result in that same experiential imprint, then we should call it torture. I defend this conception of torture in Section 2.

${ }^{36}$ This also reflects a reluctance on the part of courts to classify psychological suffering as an Eighth Amendment violation and increased deference to prison administrators on the question of when and under what conditions solitary confinement may be used (Hresko 2006, 15-16).
} 
mass incarceration rarely described as torture in the media or in political discourse?

To make the case that these practices are forms of torture is not enough. To understand the public and political unwillingness to describe these practices as torture and the social, legal, and institutional toleration of these practices, we must look more closely at how these practices are connected to the broader functioning of the U.S. prison system. In particular, we must look at the role of the prison system in enforcing and expressing racialized moral exclusion. If we focus on whether specific conditions are instances of torture, we fail to see how these conditions are made possible only through structural decisions, institutional practices, and actions that sustain and reinforce these narratives of moral exclusion. Such practices "are intelligible only in the context of the broader ideology that licenses them" (Swartzer 2019, 8). ${ }^{37}$

For example, despite the narratives of management, control, and protection that are used to justify the use of solitary confinement, the true function of solitary confinement (and its torturous nature) is demonstrated by which inmates are selected for its use and by its effects on these inmates. African American male inmates are disproportionately likely to be put in solitary confinement, but inmates may be placed in solitary confinement "because they have untreated mental illnesses, are children in need of 'protection,' are gay or transgender, are Muslim, have unpopular political beliefs, have been identified by others as gang members, or report rape or abuse by prison officials" (SolitaryWatch 2018). Once an inmate is placed in solitary confinement, their incarceration in solitary confinement is taken as further evidence of their torturability. As Dayan explains, "[h]ow do you mark inmates as different, of no redeeming value, and inherently bad? By creating conditions so awful that you send a message telling people 'outside the walls' who is dangerous, who must be treated as if an inferior and subordinate class of beings" (Dayan 2001, 22).

The language of the 'worst of the worst' that is used to describe those who are incarcerated in supermax prisons serves to make invisible the true scope of the torture of inmates by making hypervisible the narratives of wrongdoers whose monstrous crimes or inherently dangerous nature appear to justify their treatment.

Similarly, the sexual assault of inmates doesn't 'just happen.' It's not the inevitable result of imprisonment. Rather, the conditions that create the vulnerability of inmates (and of particularly vulnerable inmates) to sexual assault are structural and institutional. Funding for prisons, the design of prison bathrooms, the placement of cameras and other security and surveillance technologies, the timetabling of inmates' movements, staffing levels, availability and access to medical treatment, and available reporting

\footnotetext{
${ }^{37}$ Swartzer is not explicitly discussing torture. He makes this point in the context of discussing the message communicated via penal practices such as denial of voting rights and restrictions on housing, to critique communicative theories of punishment.
} 
mechanisms all affect inmates' vulnerability to sexual assault. Thus, even though it might seem that sexual assault is a clear-cut case of the kind of interpersonal torture discussed by Luban and Bernstein (there is, after all, an identifiable perpetrator who is knowingly and intentionally sexually assaulting a victim), to see sexual assault in prison in those terms ignores the role of structural decisions, institutional practices, and broader social, political, and legal narratives in creating inmates' vulnerability to sexual torture and sustaining the toleration of such acts of torture. The frequency and blatant toleration of sexual abuse of inmates thus serves a similar function to the use of intentional torture such as solitary confinement; it reinforces and reinscribes the moral devaluation of inmates that is already a defining feature the U.S. prison system. Vulnerability to sexual violence is part and parcel of the vulnerability "to premature social and civic death" (Guenther 2013 , 41) that is a hallmark of groups marked for moral exclusion.

The use of solitary confinement and the toleration of torture that results from sexual assault and the conditions of mass incarceration thus expresses and communicates the message of "radical hierarchy and radical worthlessness" (Luban 2014, 132) that is a defining feature of the experiential imprint of torture. However, given that many white inmates may also be subject to the torturous conditions I describe, and given that members of other vulnerable groups, such as LGBTI inmates, are also disproportionally made vulnerable to torturous conditions (particularly sexual assault), ${ }^{38}$ in what sense does the U.S. prison system reinforce and express a specifically racialized narrative of moral exclusion?

Intersections between class, race, gender identity, and sexual orientation affect inmates' vulnerability to torture in complex ways that mirror and reinforce the different categories of moral exclusion that are present in U.S. society. Who is made vulnerable to torture, therefore, tells us much about the background narratives of moral exclusion that make such vulnerability possible and that are reflected by public and political indifference toward the victims of torture. In focusing on race here, I do not intend to ignore or minimize the ways in which these other categories of moral exclusion intersect to shape inmates' vulnerability to torturous conditions in prisons. I focus on race because it is arguably the dominant category of moral exclusion that is expressed through and reinforced by the functioning of the prison system.

Racial bias is embedded within the criminal justice system. The association of criminality with blackness emerged soon after the end of slavery with the development of the convict lease system that was designed to "exploit the labor of Black Americans through the attribution of criminality as a racialized character of Black Americans" (Pitts 2015, 273). ${ }^{39}$ As Steven

\footnotetext{
${ }^{38}$ For example, inmates who identify as lesbian, gay, bisexual, or other encountered sexual abuse from other inmates at a rate ten times higher than inmates who identify as straight (Beck et al. 2013. See also Yurcaba 2018).

${ }^{39}$ See Alexander 2011, and Muhammad 2010 for historical analyses of this process.
} 
Swartzer notes, there is compelling evidence that, historically, "American criminal justice has played an integral role in communicating and enacting white supremacist ideologies" (Swartzer 2019, 8). ${ }^{40}$ Today, racial bias occurs at every level of interaction between the criminal justice system and the community. African Americans are disproportionately targeted in traffic stops and by "stop and frisk" policies (Butler 2014). They are subject to disproportionately higher rates of police violence (including lethal violence) (Swaine and McCarthy 2017), and they are arrested, convicted, sentenced, and incarcerated at higher rates than white people who commit similar acts (Swartzer 2019, 11). People of color are also sentenced to harsher punishments than white people who are convicted for similar crimes (Swartzer 2019, 12), and there is greater public support for harsh sentencing and harsh punishments when those subjected to it are presented as black (Hetey and Eberhardt 2014). The association of blackness with criminality is so deeply embedded in U.S. society that "the more stereotypically Black a person's physical features are perceived to be, the more that person is perceived as criminal" (Hetey and Eberhardt 2014, 1949). This perception has a direct impact on sentencing, even in death penalty cases: "after accounting for the victim's race, black and brown people are more likely to receive the death penalty than convicted white killers-especially if they look more stereotypically black" (Swartzer 2019, 12).

As a result, the function and toleration of torturous conditions in U.S. prisons, and the disproportionate vulnerability of people of color to these conditions, is explicable only through the lens of this racial bias and the multiple ways in which this racial bias permeates every aspect of the criminal justice system:

Given that the American carceral system had its origins in an explicitly white supremacist ideology, and given that this ideology continues to strongly influence policymakers and the public, the harsh and racially-biased measures characteristic of American policing and punishment are most reasonably understood as continuing expressions of [white supremacist ideology]. (Swartzer 2019, 13)

The account of torture that I defend in this article thus enables us not only to identify conditions within U.S. prisons as torturous because of their effects on inmates, but also elucidates how the political, legal, and public acceptance of such torture (and dismissal of the victims' suffering) arises from and sustains this function of the U.S. prison system as a mechanism for racialized moral exclusion. ${ }^{41}$

\footnotetext{
${ }^{40}$ See, for example, Alexander 2011 and Muhammad 2010.

${ }^{41}$ To be clear, I am not claiming that every inmate within the U.S. prison system will experience torture or that every prison, jail, or detention center creates the conditions of torture within its walls. But this does not alter the fact that the U.S. prison system is an institution structured by and shaped on the basis of relationships of domination and moral exclusion that are characteristic of torture, and that make inmates vulnerable to the experience of torture. Arguably, what prevents a particular prison from instantiating the torturous nature of the
} 


\section{Conclusion}

I argue that we should think of torture in terms of the experiential imprint that torture creates, rather than in terms of the relationship between torturer and victim. Understanding torture in this way allows us to see how institutional structures and practices can create the conditions of torture and communicate torture's message of moral exclusion without any individual intending to commit torture. The U.S. prison system exemplifies such a torturous institution. Through a combination of direct and indirect torture sustained by racialized narratives of criminality, the functioning of the U.S. prison system expresses and reinforces the moral exclusion of those made vulnerable to torturous incarceration, who are disproportionately people of color. The public, legal, and political acceptance of the torture of inmates (despite the valiant efforts of prison activists and protest groups) and the reluctance to describe torturous conditions as torture reveals how deeply embedded are the racialized narratives of criminality and moral exclusion that create the conditions of torture and yet render invisible those who are tortured. But without an account of institutional or structural torture such as the one that I propose, we will fail to see the ways in which the use and toleration of torture is only made possible, and made sense of, through these institutionalized narratives of racialized moral exclusion.

By expanding the concept of torture to include the possibility of institutional and structural forms of torture, far from diluting the normative significance of the word 'torture,' my account enables an understanding and recognition of the suffering caused by institutional and structural practices that create conditions of vulnerability to suffering and express and reinforce moral exclusion. My approach thus has the potential to be applied to other institutional and structural forms of suffering not previously conceptualized as torture, such as certain kinds of extreme poverty, as I suggested in Section 2. Recognizing such kinds of suffering as torture would give appropriate normative weight to the experiences of those made vulnerable to such suffering and could prompt a more urgent political, legal, and public response to the practices and narratives that create and sustain the toleration of these forms of suffering.

Jessica Wolfendale

Marquette University

E-mail: Jessica.Wolfendale@marquette.edu

\section{References:}

Alexander, Michelle. 2011. The New Jim Crow: Mass Incarceration in the Age of Colorblindness. New York: The New Press.

Allhof, Fritz. 2012. Terrorism, Ticking Time-Bombs, and Torture: A Philosophical Analysis. Chicago: University of Chicago Press.

prison system is not adherence to the norms, structural practices, and policies that typify the prison system, but deviance from those norms and practices. 
Améry, Jean. 1980. At the Mind's Limits: Contemplations by a Survivor of Auschwitz and Its Realities. Bloomington, IN: Indiana University Press.

Baron, Marcia. 2018. "The Ticking Bomb Hypothetical." In Confronting Torture: Essays on the Ethics, Legality, History, and Psychology of Torture, edited by Scott A. Anderson and Martha C. Nussbaum, 177-194. Chicago, IL: University of Chicago Press.

Basoglu, Metin, Maria Livanou, and Cvetana Crnobaric. 2007. "Torture vs Other Cruel, Inhuman, and Degrading Treatment: Is the Distinction Real or Apparent?" Archives of General Psychiatry 64 (3): 277-285. https://doi.org/10.1001/archpsyc.64.3.277.

Beck, J. Allen, Marcus Berzofsky, Rachel Caspar, and Christopher Krebs. 2013. "Sexual Victimization in Prisons and Jails Reported by Inmates." National Inmate Survey, 20112012. https://www.bjs.gov/content/pub/pdf/svpjri1112.pdf.

Bernstein, J. M. 2015. Torture and Dignity: An Essay on Moral Injury. Chicago, IL: University of Chicago Press.

Betz, Joseph. 2006. “The Definition of Torture." Social Philosophy Today 22: 127-135. https://doi.org/10.5840/socphiltoday2006226.

Breyer, Thiemo. 2017. "Violence as Violation of Experiential Structures." Phenomenology and Cognitive Sciences 16 (4): 737-751. https://doi.org/10.1007/s11097-016-9476-9.

Brison, Susan. 2002. Aftermath: Violence and the Remaking of a Self. Princeton, NJ: Princeton University Press.

Bruenig, Elizabeth Stoker. 2015. "Why Americans Don't Care About Prison Rape and What Happens When the Problem Escapes from Behind Bars." The Nation. March 2, 2015. https://www.thenation.com/article/why-americans-dont-care-about-prison-rape/.

Butler, Pau. 2014. "Stop and Frisk and Torture-Lite: Police Terror of Minority Communities." Ohio State Journal of Criminal Law 12 (1): 57-69.

Cole, David. 2009. The Torture Memos: Rationalizing the Unthinkable. New York: The New Press.

“Complex Enforcement: Unconstitutional Prison Condition.” 1981. Harvard Law Review 94 (3): 626-646. https://doi.org/10.2307/1340680.

Costa, Pedro da. 2019. "Housing Discrimination Underpins the Staggering Wealth Gap Between Blacks and Whites." Economic Policy Institute Working Economics Blog. April 8, 2019. https://www.epi.org/blog/housing-discrimination-underpins-the-staggering-wealthgap-between-blacks-and-whites/.

Dayan, Colin. 2007. The Story of Cruel and Unusual. Cambridge, MA: The MIT Press.

Dayan, Colin. 2011. The Law Is a White Dog: How Legal Rituals Make and Unmake Persons. Princeton, NJ: Princeton University Press.

Dayan, Joan. 2001. "Legal Slaves and Civil Bodies." Nepantla: Views from South 2 (1): 3-39.

Dixon, Bruce A. 2010. “GA Prison Inmates Stage 1-Day Peaceful Strike Today.” Black Agenda Report. December 9, 2010. https://blackagendareport.com/content/ga-prisoninmates-stage-1-day-peaceful-strike-today.

Epps, Garrett. 2019. "Unusual Cruelty at the Supreme Court: Justice Neil Gorsuch warmly embraces state killing - even if the state knowingly inflicts agony in the process." The Atlantic. April 4, 2019. https://www.theatlantic.com/ideas/archive/2019/04/bucklew-vprecythe-supreme-court-turns-cruelty/586471/.

Feministo. 2016. “Debunking Myths About Rape in Prison.” November 14, 2016. http: //www.femifesto.ca/debunking-myths-about-prison-rape/.

Frye, Marilyn. 1983. "Oppression.” In The Politics of Reality: Essays in Feminist Theory, 1-16. New York: Crossing Press.

Guenther, Lisa. 2013. Solitary Confinement: Social Death and its Afterlives. Minneapolis, MN: University of Minnesota Press.

Harding, Kate. 2015. Asking for It: The Alarming Rise of Rape Culture-And What We Can Do about It. Boston, MA: De Capo Press.

Hetey, Rebecca C. and Jennifer L. Eberhardt. 2014. "Racial Disparities in Incarceration Increase Acceptance of Punitive Policies." Psychological Science 25 (10): 1949-1954. 
https://doi.org/10.1177/0956797614540307.

Hoffman, Kelly M., Sophie Trawalter, Jordan R. Axt, and M. Normal Oliver. 2016. "Racial Bias in Pain Assessment and Treatment Recommendations, and False Beliefs about Biological Differences Between Blacks and Whites." Proceedings of the National Academy of Sciences of the United States of America 113 (6): 4296-4301. https://doi.org/10.1073/pnas.1516047113.

Hresko, Tracy. 2006. "In the Cellars of the Hollow Men: Use of Solitary Confinement in U.S. Prisons and its Implication Under International Laws Against Torture.” Pace University School of Law International Law Review 18 (1): 1-27.

Human Rights Watch. 2004. "The Legal Prohibition Against Torture.” https://www.hrw.org/ news/2003/03/11/legal-prohibition-against-torture\#.

Jankovic, Marija and Kirk Ludwig, eds. 2018. The Routledge Handbook of Collective Intentionality. New York: Routledge.

Levinson, Sanford. 2007. "Slavery and the Phenomenology of Torture." Social Research 74 (1): 149-68.

Liptak, Adam. 2019. "Rancor and Raw Emotion Surface in Supreme Court Death Penalty Ruling.” New York Times. April 1, 2019. https://www.nytimes.com/2019/04/01/us/politics/ supreme-court-death-penalty.html.

Luban, David. 2014. Torture, Power, and Law. Cambridge UK: Cambridge University Press.

Manne, Kate. 2016. "The Logic of Misogyny." Boston Review: A Political and Literary Forum. July 11, 2016. http://bostonreview.net/forum/kate-manne-logic-misogyny.

McMahan, Jeff. 2018. "Torture and Method in Moral Philosophy." In Confronting Torture: Essays on the Ethics, Legality, History, and Psychology of torture, edited by Scott A. Anderson and Martha C. Nussbaum, 195-219. Chicago, IL: University of Chicago Press.

Mears, Daniel P. 2013. "Supermax Prisons: The Policies and the Evidence." Criminology and Public Policy 23 (4): 681-719.

Morris, Thomas D. 1996. Southern Slavery and the Law. Chapel Hill, NC: The University of North Carolina Press.

Muhammad, Khalil Gibran. 2010. The Condemnation of Blackness: Race, Crime, and the Making of Modern Urban America. Cambridge, MA: Harvard University Press.

Pettit, Phillip. 1997. Republicanism: A Theory of Freedom and Government. Oxford: Oxford Unversity Press.

Pierce, Andrew. 2014. "Structural Racism, Institutional Agency, and Disrespect." Journal of Philosophical Research 39: 23-42. https://doi.org/10.5840/jpr20147218.

Pitts, Andrea J. 2015. "White Supremacy, Mass Incarceration, and Clinical Medicine: A Critical Analysis of U.S. Correctional Healthcare." Radical Philosophy Review 18 (2): 267-85. https://doi.org/10.5840/radphilrev201412827.

Printzlau, Gry Ardal. 2018. "Feeling Less Than Real: Alterations in Self-experience After Torture." The Journal of the British Society for Phenomenology 49 (3): 205-216. https: //doi.org/10.1080/00071773.2018.1434964.

Reiter, Keramet Ann. 2012. "The Most Restrictive Alternative: A Litigation History of Solitary Confinement in US Prisons, 1960-2006." In Studies in Law, Politics, and Society, edited by Austin Sarat, Vol. 57, 71-124. Bingley, UK: Emerald Group.

Reiter, Keramet Ann. 2014. "The Supermax Prison: A Blunt Means of Control, or a Subtle Form of Violence?” Radical Philosophy Review 17 (2): 457-75. https://doi.org/10.5840/ radphilrev201491623.

Rejali, Darius. 2007. Torture and Democracy. Princeton, NJ: Princeton University Press.

Rijt, Jan-William. 2016. "Torture, Dignity, and Humiliation." The Southern Journal of Philosophy 54 (4): 480-501. https://doi.org/10.1111/sjp.12204.

Scarry, Elaine. 1985. The Body in Pain: The Making and Unmaking of the World. New York: Oxford University Press.

SolitaryWatch. 2018. "FAQ: Solitary Confinement in the United States." https://solitarywatch. org/wp-content/uploads/2019/05/Solitary-Confinement-FAQ-2018-final.pdf. 
Steinhoff, Uwe. 2013. On the Ethics of Torture. Albany, NY: State University of New York Press.

Stone-Mediatore, Shari. 2019. "How America Disguises its Violence: Colonialism, Mass Incarceration, and the Need for Resistant Imagination." Critical Review of International Social and Political Philosophy 22 (5): 542-61. https://doi.org/10.1080/13698230.2019. 1565698.

Sussman, David. 2005. "What's Wrong with Torture?” Philosophy \& Public Affairs 33 (1): 1-33. https://doi.org/10.1111/j.1088-4963.2005.00023.x.

Swaine, John and Ciara McCarthy. 2017. "Young Black Men Again Faced Highest Rate of U.S. Police Killings in 2016." The Guardian. January 8, 2017. https://www.theguardian.com/usnews/2017/jan/08/the-counted-police-killings-2016-young-black-men.

Swartzer, Steven. 2019. "Race, Ideology, and the Communicative Theory of Punishment." Philosophers' Imprint 19 (53): 1-22.

Tillerman, Jacobo. 1981. Prisoner Without a Name, Cell Without a Number. Madison, WI: University of Wisconsin Press.

van Grunsven, Janna. 2014. "The Body Exploited: Torture and the Destruction of Selfhood." In Plessner's Philosophical Anthropology, edited by Jos de Mul, 149-162. Amsterdam: Amsterdam University Press.

Wacquat, Loïc. 2009. Prisons of Poverty. Minneapolis, MI: Regents of the University of Minnesota.

Wang, Amy B. 2019. "Protesters Swarm Brooklyn Jail That Endured Polar Vortex With No Heat." The Washington Post. February 3, 2019. https://www.washingtonpost.com/nation/2019/02/03/protesters-swarm-dark-freezingbrooklyn-jail-that-endured-polar-vortex-with-no-heat/.

Wolfe, Abram. 2019. "Solitary Confinement in Immigration Detention is a Grim Reality-and Only Likely to Get Worse." Solitary Watch. July 30, 2019. https://solitarywatch.org/2019/07/30/solitary-confinement-in-immigration-detention-isa-grim-reality-and-only-likely-to-get-worse/.

Wolfendale, Jessica. 2009. "The Myth of Torture Lite." Ethics and International Affairs 23 (1): 47-61. https://doi.org/10.1111/j.1747-7093.2009.00189.x.

Wolfendale, Jessica. 2017. “Moral Security.” The Journal of Political Philosophy 25 (2): 238-55. https://doi.org/10.1111/jopp.12124.

Woodman, Spencer and Maryam Saleh. 2019. "40 Percent of ICE Detainees Held in Solitary Confinement Have a Mental Illness, New Report Finds.” The Intercept. August 14, 2019. https://theintercept.com/2019/08/14/ice-solitary-confinement-mental-illness/.

Yurcaba, Jo. 2018. "For Survivors of Prison Rape, Saying 'Me Too' Isn't an Option." Rewire.News. January 8, 2018. https://rewire.news/article/2018/01/08/survivors-prisonrape-saying-isnt-option/. 